\title{
Occupational Exposure Limits for Enzymes: Practical Considerations
}

\author{
David Basketter $^{1 *}$, Nuria Moreno ${ }^{2}$ and Merete Simonsen ${ }^{3}$ \\ ${ }^{1}$ DABMEB Consultancy Ltd, Kingswood, UK \\ ${ }^{2}$ Association of Manufacturers and Formulators of Enzyme Products, Belgium \\ ${ }^{3}$ Novozymes A/S, Denmark
}

Submission: March 15, 2021; Published: March 26, 2021

*Corresponding author: Dr. David Basketter, DABMEB Consultancy Ltd, Abbey View, Abbey Street, Kingswood, Gloucestershire GL12 8RN, UK

Keywords: Enzymes; Respiratory sensitisation; Airborne exposure; Respiratory allergen; IgE mediated allergy

Abbreviation: OEL: Occupational Exposure Limits; DMEL: Derived Minimal Effect Level

\section{Commentary}

A commentary article in this journal encouraged us all to work towards evidence-informed occupational airborne exposure limits for enzymes [1]. This prompted a response and a subsequent reply which explored a little more of the challenges faced $[2,3]$. Where there was debate, it might be best characterised as differences in the emphasis placed on the extent to which pragmatism should dominate decision-making, coupled with the ongoing need to ensure that complacency does not appear in industries that regard themselves as under control. It is a key principle that worker protection is an essential activity which should be based on the best evidence available and can be demonstrated to be successful, as in the report on 5 years of occupational health and air monitoring from a number of enzyme using detergent factories [4].

As enzymes are well known respiratory allergens, responsible users in the detergent industry have worked for half a century to an accepted and internationally recognised standard to protect worker health $[5-7,4]$.

An important aspect here is that industry groups have taken the lead in the dissemination of best practice and have updated published industry guidance on multiple occasions, the latest version of which can be accessed here [8,9]. In addition, the knowledge originating from the enzyme manufacturing industry has been regularly published [10-12]. This has provided the basis on which best practice has been extended to other/downstream industries.
In principle, the matter of establishing an occupational exposure limit for a respiratory allergen is no different to other toxicology endpoints: identify the hazard, characterise the doseresponse (potency assessment), understand the nature and extent of human exposure and use the combined information to set a safe level. For protein respiratory allergens, the challenges associated with this include the limited understanding of the dose response metrics [13-15]. This has led to a practical working solution, setting a derived minimal effect level (DMEL), which has already been published [16]. It has been argued that strict adherence to this approach involving use of the $60 \mathrm{ng} / \mathrm{m}^{3}$ as a starting point benchmark has delivered a high level of occupational safety $[7,4]$. Central to this is rigorous application of occupational hygiene, with constant air monitoring and regular occupational health surveillance. Significantly, failure to adhere to the guidance leads to occupational health problems [17].

It has to be admitted that imperfections remain in the epidemiological metrics, the risk calculations and missing exposure information. Undoubtedly better epidemiological information would be a real asset. Similarly, it would be easy to assert that fuller exposure information must be helpful. These should then permit better risk calculations of course. However, there remains a genuine practical problem-that of matching exposure data, even from personal exposure monitoring to the acquisition of IgE mediated allergy. There is little evidence to indicate whether short term peak exposures are more, or less, 
important than repeated or constant lower level exposure and although the respiratory tract is the primary candidate, there is limited formal evidence for which route of exposure is actually critical to the induction of sensitisation. Finally, as far as we are aware, there have been no clinical experimental studies in which naïve volunteers have been subjected to defined inhalation exposures in order to characterise the parameters of exposure and dose which lead to the acquisition of IgE mediated allergy.

All of these considerations and uncertainties lead inexorably to the pragmatic approach in which general airborne exposure levels are linked to the presence/absence of IgE allergies. Such an approach has the benefit that it avoids the potential inertia that can be associated with situations where there is not sufficient hard data to derive a fully evidence-based OEL. Perhaps such a problem occurred with the important efforts to establish an OEL for $\alpha$-amylase, where it appeared that gaining substantial exposure data from all users sectors tended to stall the establishment of a suitable and broadly agreed value $[18,19]$. Of particular note was the concern from the UK perspective that the exposure-response relationships leading to the proposal for an airborne limit of $<1 \mathrm{ng} / \mathrm{m}^{3}$ was not well founded. On a more positive note, it was encouraging that the induction of antigen specific IgE was seen as the most appropriate measure on which to focus, in accord with the principle followed by the enzyme industry for several decades.

What are the essentials for a more pragmatic approach? There are three elements, each considered in a brief detail below:

The first essential has been the recognition of problematic exposure levels, and from that knowledge has evolved a definition of an exposure benchmark (usually designated as the DMEL), from which are determined exposure limits that can be achieved and accurately monitored [7,10-12,4,16]. It is not necessary here to review the history of occupational asthma problems that challenged the detergent industry in the mid-20 $0^{\text {th }}$ century [2022]. What was gleaned from this unfortunate experience was an understanding of airborne exposure levels which delivered worker safety [5].

The second essential is that once there is general acceptance of what constitutes a suitable occupational exposure limit (OEL), the focus then must be directed towards compliance and monitoring. Any OEL is only of value where there is proper adherence thereto. Although perfection in this respect may be difficult, the data from approximately 100 industrial sites across 5 continents over a period of 5 years demonstrated a very high level of compliance (>99\%) [4]. This suggests what can be achieved in the real world. Furthermore, health monitoring on the associated workforce (with almost 96\% uptake) demonstrated an absence of any symptoms in $99.9 \%$. It is worth diverting to remark that the occupational health default is to assume that symptoms (any one of rhinitis, conjunctivitis, impaired lung function and asthma) are assumed to be work-related unless they can be clearly linked to a non-occupational cause.
In other words, once proper control is achieved, the prevalence of workers with symptomatic occupational IgE allergy to enzymes in these industries is likely to be distinctly lower than 1 in a 1000 . In support of this, the experience of almost 50 years of dealing with occupational allergy to enzymes in one company has been reported [12]. These authors demonstrated how with increasing experience the risk of allergy was reduced each decade, despite being paralleled in reverse by increasing production volumes, concluding "For primary prevention of enzyme allergy, exposure control is mandatory and achievable.... These conclusions were reached via a retrospective evaluation of $>5000$ employees, sorted into 5 exposure group level and subject to regular health monitoring. The induction of $\operatorname{IgE}$ was related to exposure level and smoking; a high level of IgE was the sole risk factor for the expression of symptoms.

The third and critical aspect of the pragmatic strategy is the recognition that the hazard and the risks to human health associated with that intrinsic hazard never go away, nor do they ameliorate over time. Consequently, they require sustained vigilance. Complacency in the workforce and/or the management has to be avoided. Importantly, it is also necessary for the industry involved to promulgate best practice (whilst complying with anti-trust legislation). Enzyme producers and enzyme detergent industries have a good track record in this respect, working to ensure that advice is appropriate, clear and up to date $[8,23]$. Where possible, to encourage the adoption of practical best practice, that advice has been extrapolated to other downstream enzyme users, such as baking [9] and the pulp and paper industry [24] as well as to consumer products [25]. These considerations have extended even to $3^{\text {rd }}$ party suppliers and logistics [26].

Whilst accepting that this industry's approach has been based on an exposure limit that had to be defined, and broadly accepted, despite a less than an ideal level of supporting evidence, industry success has been well documented $[4,12]$. If this degree of success could be translated to other industries with an existing enzyme occupational respiratory allergen problem, it offers the prospect of improving significantly the working environment in those industries [2]. This conclusion that was expressed only recently continues to have merit.

\section{Declaration}

DAB was funded by the Association of Manufacturers and Formulators of Enzyme Products for the preparation and submission of this letter; NM and MS are fully paid employees of their respective organisations. DAB has been funded by both the Association of Manufacturers and Formulators of Enzyme Products and by Novozymes for a range of consultancy activities regarding enzyme allergy over the last 10 years.

\section{References}

1. Heederik DJJ (2019a) Towards evidence informed occupational exposure limits for enzymes. Ann Work Expo Health 63(4): 371-374. 
2. Basketter D, Fox P, Simonsen M (2019) Evidence-Informed Occupational Exposure Limits for Enzymes. Annals of Work Exposures and Health 63(9): 1081-1082.

3. Heederik D (2019b) Response to Basketter et al. on Towards evidence informed occupational exposure limits for enzymes. Ann Work Expo Health 63(9): 1083-1084.

4. Basketter DA, Kruszewski FH, S Mathieu, Donald BK, Anthony P, et al. (2015) Managing the risk of occupational allergy in the enzyme detergent industry. J Occup Environ Hygiene 12(7): 431-437.

5. ACGIH (2001) American Conference of Governmental and Industrial Hygienists: Subtilisins: TLV® Chemical Substances 7th Edition.

6. Sarlo K, Kirchner DB (2002) Occupational asthma and allergy in the detergent industry: new developments. Curr Opin Allerg Clin Immunol 2(2): 97-101.

7. Sarlo K (2003) Control of occupational asthma and allergy in the detergent industry. Ann Allergy Asthma Immunol 90(5): 32-34.

8. AMFEP (2013) Guide to the safe handling of industrial enzyme preparations. Association of Manufacturers and Formulators of Enzyme Products.

9. AMFEP/FEDIMA (2018) Industry guidelines on the safe handling of enzymes in the bakery supply chain. Association of Manufacturers and Formulators of Enzyme Products and the Federation of European Union Manufacturers and Suppliers of Ingredients to the Bakery, Confectionary and Patisserie Industries.

10. Johnsen CR, Sorensen TB, Larsen AI, AB Secher, E Andreasen, et al. (1997) Allergy risk in an enzyme producing plant: a retrospective follow up study. Occup Environ Medicine 54(9): 671-675.

11. Larsen AI, Johnsen CR, Frickmann J, S Mikkelsen (2007) Incidence of respiratory sensitisation and allergy to enzymes among employees in an enzyme producing plant and the relation to exposure and host factors. Occup Environ Med 64(11): 763-768.

12. Larsen AI, Cederkvist L, Lykke AM, Poul W, Claus RJ, et al. (2020) Allergy Development in Adulthood: An Occupational Cohort Study of the Manufacturing of Industrial Enzymes. J All Clin Immunol: In Practice 8(1): 210-218.

13. Arts JH, Mommers C, De Heer C (2006) Dose-response relationships and threshold levels in skin and respiratory allergy. Crit Rev Toxicol 36(3): 219-251.

14. Blackburn K, N Jai AU, Dearman RJ, Ian K, G Frank G (2015) Respiratory allergenic potential of plant-derived proteins: Understanding the relationship between exposure and potency for risk assessments. Crit Rev Toxicol 45(9): 799-811.
15. Yokozeki K, Yuki T, Ogasawara A, Katagiri A, Takahashi Y, et al. (2020) Total exposure defines the incidence of percutaneous IgE/IgG1 mediated immediate type hypersensitivity caused by papain. J Appl Toxicol.

16. Basketter DA, Broekhuizen C, Fieldsend M, S Kirkwood, R Mascarenhas, et al. (2010) Defining occupational and consumer exposure limits for enzyme protein respiratory allergens under REACH. Toxicology 268(3): 165-170.

17. Cullinan P, Harris JM, Newman Taylor AJ, A M Hole, M Jones, et al (2000) An outbreak of asthma in a modern detergent factory. Lancet 356(9245): 1899-1900.

18. Health Council of the Netherlands (2014) Fungal alpha-amylase (derived from the fungus Aspergillus oryzae) Health-based recommended occupational exposure limit.

19. UK HSE (2016) Substance Evaluation Conclusion and Evaluation report for a-Amylase. Dated July 2016. EC No 232-565-6.

20. Flindt ML (1969) Pulmonary disease due to inhalation of derivatives of Bacillus subtilis containing proteolytic enzyme. Lancet 1(7607): 11771181.

21. Pepys J, Longbottom JL, Hargreave FE, J Faux (1969) Allergic reactions of the lungs to enzymes of Bacillus subtilis. Lancet 1(7607): 11811184.

22. Juniper CP, How MJ, Goodwin BFJ, AK Kinshott (1977) Bacillus subtilis: A 7 year clinical, epidemiological and immunological study of an industrial allergen. J Soc Occup Med 27(1): 3-12.

23. AISE (2018) Guidelines for the safe handling of enzymes in detergent manufacturing. Book Guidelines for the safe handling of enzymes in detergent manufacturing. Version 2.2, Brussels, Belgium: International Association for Soaps, Detergents and Maintenance Products.

24. AMFEP/CEPI (2019) Industry Guidelines on the Safe Handling of Enzymes in Pulp \& Paper Manufacturing. Association of Manufacturers and Formulators of Enzyme Products and the Confederation of European Paper Industries.

25. ACI (2019) Guidance for the risk assessment of enzyme-containing consumer products. American Cleaning Institute.

26. AISE (2020) Enzyme Safety Operational Guidance for 3rd Party (3PL) Logistics Suppliers. International Association for Soaps, Detergents and Maintenance Products.

\section{Your next submission with Juniper Publishers} will reach you the below assets

- Quality Editorial service

- Swift Peer Review

- Reprints availability

- E-prints Service

- Manuscript Podcast for convenient understanding

- Global attainment for your research

- Manuscript accessibility in different formats ( Pdf, E-pub, Full Text, Audio)

- Unceasing customer service

Track the below URL for one-step submission https://juniperpublishers.com/online-submission.php 